\title{
Tumour growth-suppressive effect of arsenic trioxide in squamous cell lung carcinoma
}

\author{
LEANNE LEE LEUNG ${ }^{*}$, SZE-KWAN LAM ${ }^{*}$, YUAN-YUAN LI and JAMES CHUNG-MAN HO \\ Division of Respiratory Medicine, Department of Medicine, \\ The University of Hong Kong, Queen Mary Hospital, Hong Kong, SAR, P.R. China
}

Received November 30, 2015; Accepted April 24, 2017

DOI: $10.3892 / \mathrm{ol} .2017 .6646$

\begin{abstract}
Lung squamous cell carcinoma (SCC) is the second most common subtype of non-small cell lung carcinoma. The anticancer effects of arsenic trioxide (ATO) in lung adenocarcinoma and small-cell lung cancer have previously been reported; however its effects in SCC remain unclear. An MTT assay and western blot analysis were performed to determine cell viability and protein expression, respectively, in the SK-MES-1 and SW900 SCC cell lines following treatment with ATO. Phosphatidylserine externalization, mitochondrial membrane depolarization and cell cycle distribution were studied using flow cytometry and the in vivo effects of ATO on tumour growth were investigated with a xenograft model. The results demonstrated that SK-MES-1 and SW900 SCC cells were sensitive to clinically relevant concentrations of ATO.ATO induced apoptosis, mitochondrial membrane depolarization and $\mathrm{G}_{2} / \mathrm{M}$ arrest. In addition, treatment with ATO resulted in the downregulation of $\mathrm{X}$-linked inhibitor of apoptosis, B-cell lymphoma-2 (Bcl-2), E2F transcription factor 1 (E2F1), thymidylate synthase and ribonucleotide reductase $\mathrm{M} 1$ in addition to the upregulation of Bcl-2 antagonist/killer protein, cleaved poly ADP-ribose polymerase and cleaved caspase 3 in a cell-line specific manner. In the SW900 xenograft model, tumour growth was inhibited by ATO with the formation of apoptotic bodies and downregulation of Bcl-2 and E2F1. In conclusion, ATO suppresses the growth of SCC in vitro and in vivo.
\end{abstract}

Correspondence to: Dr James Chung-Man Ho, Division of Respiratory Medicine, Department of Medicine, The University of Hong Kong, Queen Mary Hospital, 102 Pok Fu Lam Road, Hong Kong, SAR, P.R. China

E-mail: jhocm@hku.hk

*Contributed equally

Key words: squamous cell lung carcinoma, arsenic trioxide, apoptosis, xenograft

\section{Introduction}

Lung cancer was responsible for the majority of cancer-associated mortalities in China in 2014, with risk factors attributed to tobacco or asbestos exposure, indoor air pollution, carcinogenic products and genetic susceptibility (1). Lung cancer can be divided into non-small cell lung cancer (NSCLC) and small cell lung cancer (SCLC); $85 \%$ of cases are NSCLC (2). The major histological subtypes of NSCLC include adenocarcinoma, squamous cell carcinoma (SCC) and large cell carcinoma (3), with distinct phenotypes. SCC is the second most prevalent $(\sim 30 \%)$ among cases of NSCLC. Despite the recent advances of targeted therapy in lung adenocarcinoma, platinum doublet chemotherapy remains the cornerstone treatment in metastatic SCC of the lung (4).

Arsenic trioxide (ATO) has previously been used as a traditional Chinese medicine; synergistic combination of ATO with all-trans retinoic acid (ATRA) has been demonstrated to lower the relapse rate during treatment of acute promyelocytic leukaemia (APL) (5). ATO activates the caspase signalling pathway, decreases the mitochondrial membrane potential and promotes the production of reaction oxygen species (ROS), leading to apoptosis (6). In addition, ATO induces apoptosis by downregulating $\mathrm{B}$-cell lymphoma-2 (Bcl-2) and inducing $\mathrm{G}_{2} / \mathrm{M}$ cell cycle arrest (7).

The anticancer activity of ATO has been reported in other solid tumours (8). In addition, a previous study from our group reported the in vitro and in vivo activity of ATO in SCLC (9). Given the limited therapeutic options in advanced lung SCC, the aim of the present study was to investigate the role of ATO in treatment of SCC using in vitro cell line and in vivo tumour xenograft models.

\section{Materials and methods}

Cell lines and reagents. A panel of 4 squamous cell lung carcinoma cell lines was obtained from American Type Culture Collection (Manassas, VA, USA). SK-MES-1 and SW900 cells were cultured in Eagle's Minimum Essential Medium (Gibco; Thermo Fisher Scientific, Inc., Waltham, MA, USA) and Leibovitz's L-15 medium (Gibco; Thermo Fisher Scientific, Inc.), respectively. H520 and H2170 cells were cultured in RMPI-1640 medium (Gibco; Thermo Fisher Scientific, Inc.). All media were supplemented with $10 \%$ foetal bovine serum 
(Gibco; Thermo Fisher Scientific, Inc.). Cells were incubated at $37^{\circ} \mathrm{C}$ in a humidified atmosphere supplied with $5 \% \mathrm{CO}_{2}$. ATO (Sigma-Aldrich; Merck KGaA, Darmstadt, Germany) was dissolved in $1.65 \mathrm{M} \mathrm{NaOH}$ in a final concentration of $2.5 \mathrm{mM}$.

Cell viability assay. MTT assay was performed as previously described (10). SK-MES-1 (2,000 cells/well), SW900 (20,000 cells/well), H520 (10,000 cells/well) or H2170 (20,000 cells/well) cells were seeded in 96-well plate overnight at $37^{\circ} \mathrm{C}$. Cells were incubated for $72 \mathrm{~h}$ with ATO solution $(0.625,1.25,2.5,5,10$ and $20 \mu \mathrm{M})$ and untreated cells served as a control. Cells were further incubated at $37^{\circ} \mathrm{C}$ for $2 \mathrm{~h}$ following addition of $20 \mu \mathrm{l}$ of MTT solution $(0.25 \mathrm{mg} / \mathrm{ml}$ final concentration) (USB Corporation, Cleveland, OH, USA). All solutions were then removed and $50 \mu \mathrm{l}$ dimethyl sulfoxide was added to solubilize the formazan crystals. Optical density was measured at $570 \mathrm{~nm}$ using a FLUOstar OPTIMA micro-plate reader (BMG Labtech $\mathrm{GmbH}$, Ortenberg, Germany). All experiments were performed $\geq 3$ times.

Annexin binding assay. Annexin binding assay was performed using an annexin V-phycoerythrin (PE)/7-aminoactinomycin D (7-AAD) apoptosis detection kit (BD Biosciences, Franklin Lakes, NJ, USA) (9). Cells were treated for $72 \mathrm{~h}$ with ATO $(1.25,2.5$ and $5 \mu \mathrm{M})$ and untreated cells served as a control. Cells $\left(1 \times 10^{6}\right)$ were collected, washed with PBS and re-suspended in binding buffer. Cells were then stained for $15 \mathrm{~min}$ at room temperature in darkness with $300 \mu \mathrm{l}$ binding buffer containing $5 \mu \mathrm{l}$ of annexin V-PE and $5 \mu \mathrm{l}$ of 7-AAD. The excitation/emission (Ex/Em) of PE-annexin $\mathrm{V}$ and 7-AAD were 488/578 and 546/647 $\mathrm{nm}$, respectively. Signals were detected using a flow cytometer (Cytomics FC500 with CXP software version 1.0, Beckman Coulter, Inc., Brea, CA, USA) using Fluorescence Light (FL), FL2 and FL4 channels. A total of 10,000 events/sample were recorded. The percentage of apoptotic cells (PE+/7-AADand $\mathrm{PE}+/ 7-\mathrm{AAD}+)$ was calculated. The experiments were performed in triplicate.

Mitochondrial membrane depolarization detection. JC-1 (Sigma-Aldrich; Merck KGaA) staining was performed as previously described (11). Cells were treated for $72 \mathrm{~h}$ with ATO $(1.25,2.5$ and $5 \mu \mathrm{M})$ and untreated cells served as a control. Cells $\left(1 \times 10^{6}\right)$ were collected, washed with PBS and stained at $37^{\circ} \mathrm{C}$ for $15 \mathrm{~min}$ in darkness with JC-1 $(2 \mu \mathrm{M}$ final concentration) in plain medium. Signals were detected using a flow cytometer (Cytomics FC500 with CXP software version 1.0, Beckman Coulter, Inc.) with FL1 and FL2 channels. A total of 10,000 events/sample were captured. The experiments were performed in triplicate.

Cell cycle analysis. Cells were treated for $72 \mathrm{~h}$ at the beginning of experiment with ATO $(1.25,2.5$ and $5 \mu \mathrm{M})$ and untreated cells served as a control. Cells were fixed with $70 \%$ cold ethanol and stored at $-20^{\circ} \mathrm{C}$. Cells were incubated at $37^{\circ} \mathrm{C}$ in the dark with plain medium containing RNase A (Thermo Fisher Scientific, Inc.) and propidium iodide (Sigma-Aldrich). Signals were detected using a flow cytometer (Cytomics FC500 with CXP software version 1.0, Beckman Coulter, Inc.) with FL3 channel.
Western blot analysis. Western blot analysis was performed as previously reported (11). Cells $\left(1 \times 10^{7}\right)$ were collected and lysed for $1 \mathrm{~h}$ on ice with RIPA buffer (20 mM Tris- $\mathrm{HCl}(\mathrm{pH} 7.5)$, $150 \mathrm{mM} \mathrm{NaCl}, 1 \mathrm{mM} \mathrm{Na}{ }_{2}$ EDTA, 1 mM EGTA, 1\% NP-40, 1\% sodium deoxycholate, $2.5 \mathrm{mM}$ sodium pyrophosphate, $1 \mathrm{mM}$ $\beta$-glycerophosphate, $1 \mathrm{mM} \mathrm{Na} \mathrm{VO}_{4}$ and $1 \mu \mathrm{g} / \mathrm{ml}$ leupeptin) containing a protease inhibitor cocktail. Tissue samples were lysed for $1 \mathrm{~h}$ on ice with T-PER ${ }^{\circledR}$ Tissue Protein Extraction Reagent (Thermo Fisher Scientific, Inc.) containing a protease inhibitor cocktail. Protein concentration was detected using a Bradford assay (Bio-Rad Laboratories, Inc., Hercules, CA, USA). Protein (25-100 $\mu \mathrm{g})$ was then mixed with a $5 \mathrm{X}$ sample buffer (0.1 M Tris-HCl, pH 6.8, 50\% glycerol, 10\% SDS, $5 \% \beta$-mercaptoethanol and $0.05 \%$ bromophenol blue) and boiled for $5 \mathrm{~min}$. Proteins were separated using SDS-PAGE (10-15\%). Proteins were then transferred to nitrocellulose blotting membranes (GE Healthcare Life Sciences, Little Chalfont, UK). The membrane was blocked at $4^{\circ} \mathrm{C}$ for $1 \mathrm{~h}$ with $5 \%$ blotting-grade blocker (Bio-Rad Laboratories, Inc.) and further incubated at $4^{\circ} \mathrm{C}$ overnight with primary antibody (Cell Signaling Technology, Inc., Danvers, MA, USA; all in 1:1,000) [rabbit anti-human Bcl-2 antagonist/killer protein (Bak) (cat no. 3814), rabbit anti-human Bcl-2 (cat no. 2872), rabbit anti-human cleaved caspase 3 (cat no. 9661), rabbit anti-human E2F transcription factor 1 (E2F1; cat no. 3742), rabbit anti-human poly ADP-ribose polymerase (PARP; cat no. 9542), rabbit anti-human ribonucleotide reductase M1 (RRM1; cat no. 8637), rabbit anti-human thymidylate synthase (TYMS; cat no. 5449) and rabbit anti-human X-linked inhibitor of apoptosis protein (XIAP; cat no. 2042)]. The membrane was washed at $4^{\circ} \mathrm{C}$ for $10 \mathrm{~min}$ with Tris-Buffered Saline and Tween 20 (TBST) 3 times. The membrane was then incubated at $4^{\circ} \mathrm{C}$ for 90 min with corresponding horseradish peroxidase-conjugated secondary antibody (anti-mouse IgG, cat no. 7076, 1:1,000 or anti-rabbit $\operatorname{IgG}$, cat no. 7074, 1:1,000; both from Cell Signaling Technology, Inc.). Protein expression was detected using Amersham ${ }^{\mathrm{TM}}$ ECL $^{\mathrm{TM}}$ Western Blotting Detection Reagents (GE Healthcare Life Sciences, catalogue no. RPN2106). Relative protein expression was normalized with mouse anti-human $\beta$-actin (Sigma-Aldrich, cat no. A1978, 1:1,000). Band intensities were analysed by GelQuant version 1.8.2 (BioSystematica, Llandysul, UK).

Tumour growth inhibition in vivo. A total of $24 \mathrm{BALB} / \mathrm{cA}$-nude mice (female, 4-6-week-old, 10-14 g, BALB/cAnN-nu, Charles River Laboratories, Wilmington, USA) were obtained and kept in $12 / 12 \mathrm{~h} \mathrm{light/dark} \mathrm{cycle} \mathrm{with} \mathrm{temperature}\left(16-26^{\circ} \mathrm{C}\right)$ and humidity (30-70\%) control and ad libitum diet was provided. The animal protocol (approval reference number: 2860-12) was approved by the Animal Ethics Committee of The University of Hong Kong. SW900 cells $\left(10^{7}\right)$ were re-suspended in $100 \mu \mathrm{l}$ phosphate buffered saline and mixed with $100 \mu$ lice-cold highly concentrated Matrigel matrix (BD Biosciences) prior to subcutaneous injection at the back of the nude mice. The mice were randomized into 3 groups $(n=8)$ when the tumour volume reached $100 \mathrm{~mm}^{3}$. PBS and ATO $(3.75$ and $7.5 \mathrm{mg} / \mathrm{kg}$ ) were injected intraperitoneally and daily in control and treatment groups, respectively. Their general condition and body weight were monitored daily. Tumour size was measured on alternate days using digital calipers and calculated using the 
formula [volume $=1 / 2 \mathrm{x}$ length $\mathrm{x}$ width $\mathrm{x}$ height] (12). The experimental endpoint was reached when the length of tumour exceeded $17 \mathrm{~mm}$ in the control group. Tumours were collected for western blot analysis and hematoxylin and eosin staining.

Hematoxylin and eosin staining. Tissues were fixed overnight at $4^{\circ} \mathrm{C}$ in PBS $10 \%$ formaldehyde. Tissues were cut into $5 \mu \mathrm{m}$ sections. The slides were deparaffinized by immersion in xylene (Merck KGaA). Subsequently, tissue sections were rehydrated with 100, 95 and 75\% ethanol (Sigma-Aldrich; Merck KGaA) and distilled water (5 min for each step). Nuclei were stained for $2 \mathrm{~min}$ at room temperature with hematoxylin (Sigma-Aldrich; Merck KGaA) and cytoplasm was stained for $30 \mathrm{sec}$ at room temperature with eosin (BD Biosciences) to visualize cellular structures. Slides were immersed in water to stop staining. For the dehydrating process, sections were dehydrated in 75,95 and $100 \%$ ethanol and xylene (5 min for each step). Slides were mounted with Histofluid (Marienfeld-Superior, Germany). Images were captured using a Nikon Ni-U fluorescence microscope (Nikon, Tokyo, Japan) equipped with a camera/detector Diagnostic Instrument RT3 Slider (Meyer Instruments, Houston, USA). Pictures were captures at x200 magnification using CFI Plan Fluor DLL 20X objective (Nikon). Images were obtained using NIS-Elements Basic Research software (Laboratory Imaging, Prague, Czech Republic).

Statistical analysis. Data from three individual experiments are presented as the mean \pm standard deviation. Comparison between groups was performed using Student's two-tailed t-test using Prism version 5.01 (GraphPad Software, Inc., La Jolla, CA, USA). $\mathrm{P}<0.05$ was considered to indicate a statistically significant difference.

\section{Results}

ATO treatment decreases SK-MES-1 and SW900 cell viability. Cell viability was reduced by ATO in a dose-dependent manner in SK-MES-1 and SW900 cells (Fig. 1A). The half-maximal inhibitory concentration $\left(\mathrm{IC}_{50}\right)$ values $(72 \mathrm{~h}$ following ATO treatment) in SK-MES-1 and SW900 cells were 2.5 and $5 \mu \mathrm{M}$, respectively, while those in H520 and H2170 cells were $>10 \mu \mathrm{M}$. SK-MES-1 and SW900 cells were selected for further experiments, as their $\mathrm{IC}_{50}$ values were within clinically reachable concentrations of ATO (13). In SK-MES-1 cells, ATO treatment markedly increased the percentage of late apoptotic cells in a dose-dependent manner, as detected using an annexin V-PE/7-AAD assay. A concentration of $5 \mu \mathrm{M}$ ATO significantly increased the percentage of late apoptotic cells compared with the control group (15 vs. $5 \%$; $\mathrm{P}<0.05$; Fig. 1B). In addition, treatment with $5 \mu \mathrm{M}$ ATO significantly increased the percentage of SK-MES-1 cells with mitochondrial membrane depolarization compared with the control group (26 vs. 12\%; $\mathrm{P}<0.05$; Fig. 1C). Cell cycle analysis using propidium iodide staining demonstrated that ATO treatment induced $\mathrm{G}_{2} / \mathrm{M}$ arrest in SK-MES-1 and SW900 cells (Tables I and II).

Expression of apoptosis and DNA replication-associated proteins following treatment with ATO. Following treatment
Table I. The percentage of cells in different phases of the cell cycle following ATO treatment in SK-MES-1 cells .

\begin{tabular}{lrrcc}
\hline & \multicolumn{5}{c}{ Cell cycle phase distribution, \% } \\
\cline { 2 - 5 } ATO dose & \multicolumn{1}{c}{ Sub- $\mathrm{G}_{1}$} & \multicolumn{1}{c}{$\mathrm{G}_{1}$} & $\mathrm{~S}$ & $\mathrm{G}_{2} / \mathrm{M}$ \\
\hline $0 \mu \mathrm{M}$ & $9.9 \pm 4.6$ & $55.1 \pm 4.0$ & $14.2 \pm 2.1$ & $20.9 \pm 2.8$ \\
$1.25 \mu \mathrm{M}$ & $11.3 \pm 4.3$ & $48.2 \pm 1.2^{\mathrm{a}}$ & $16.6 \pm 3.6$ & $23.9 \pm 2.0$ \\
$2.5 \mu \mathrm{M}$ & $12.7 \pm 3.5$ & $44.7 \pm 2.8^{\mathrm{a}}$ & $15.5 \pm 5.6$ & $27.1 \pm 0.9^{\mathrm{a}}$ \\
$5 \mu \mathrm{M}$ & $10.6 \pm 5.3$ & $36.4 \pm 1.1^{\mathrm{b}}$ & $19.0 \pm 1.3$ & $34.1 \pm 5.1^{\mathrm{a}}$
\end{tabular}

${ }^{\mathrm{a}} \mathrm{P}<0.05$ and ${ }^{\mathrm{b}} \mathrm{P}<0.01$ compared with the control. ATO, arsenic trioxide.

Table II. The percentage of cells in different phases of the cell cycle following ATO treatment in SW900 cells.

\begin{tabular}{lcccc}
\hline & \multicolumn{5}{c}{ Cell cycle phase distribution, \% } \\
\cline { 2 - 5 } ATO dose & Sub- $\mathrm{G}_{1}$ & $\mathrm{G}_{1}$ & $\mathrm{~S}$ & $\mathrm{G}_{2} / \mathrm{M}$ \\
\hline $0 \mu \mathrm{M}$ & $3.1 \pm 1.5$ & $56.8 \pm 1.9$ & $10.4 \pm 1.7$ & $29.7 \pm 1.3$ \\
$1.25 \mu \mathrm{M}$ & $2.3 \pm 0.9$ & $47.3 \pm 5.6$ & $11.4 \pm 0.5$ & $39.0 \pm 5.9$ \\
$2.5 \mu \mathrm{M}$ & $2.3 \pm 0.6$ & $44.0 \pm 1.8^{\mathrm{a}}$ & $11.6 \pm 0.2$ & $42.1 \pm 2.6^{\mathrm{a}}$ \\
$5 \mu \mathrm{M}$ & $1.9 \pm 0.3$ & $40.8 \pm 5.6^{\mathrm{b}}$ & $11.3 \pm 1.2$ & $46.0 \pm 5.4^{\mathrm{b}}$
\end{tabular}

${ }^{a} \mathrm{P}<0.01$ and ${ }^{\mathrm{b}} \mathrm{P}<0.001$ compared with the control. ATO, arsenic trioxide.

with $5 \mu \mathrm{M}$ ATO, expression of XIAP and Bcl-2 was significantly downregulated in SW900 and SK-MES-1 cells, respectively, compared with the control groups $(\mathrm{P}<0.01$ and $\mathrm{P}<0.05$; Fig. $2 \mathrm{~A}$ and $\mathrm{B}$, respectively). Bak was significantly upregulated in SW900 cells compared with the control group $(\mathrm{P}<0.05$; Fig. 2C) and expression of cleaved caspase 3 was significantly increased in SK-MES-1 and SW900 cells compared with the control groups $(\mathrm{P}<0.001$ and $\mathrm{P}<0.05$, respectively; Fig. 2D). A significant increase in cleaved PARP expression was observed in SK-MES-1 cells compared with the control group $(\mathrm{P}<0.01$; Fig. 2E). ATO $(1.25,2.5$ and $5 \mu \mathrm{M})$ treatment significantly downregulated the expression of E2F1 compared with the control group in SK-MES-1 $(\mathrm{P}<0.05, \mathrm{P}<0.001$ and $\mathrm{P}<0.001$, respectively; Fig. 2F). RRM1 expression was significantly decreased compared with the control group in SK-MES-1 cells $(2.5$ and $5 \mu \mathrm{M}$ ATO; $\mathrm{P}<0.05$ and $\mathrm{P}<0.01$, respectively; Fig. 2G) and TYMS expression was significantly decreased in SK-MES-1 cells treated with $5 \mu \mathrm{M}$ ATO compared with the control group $(\mathrm{P}<0.05$; Fig. $2 \mathrm{H})$.

In vivo effect of ATO in SW900 xenograft model. In order to assess the effect of ATO on tumour growth in vivo, mice were subcutaneously injected with SW900 cells, tumours were allowed to grow to $\sim 100 \mathrm{~mm}^{3}$, then the mice were treated daily with PBS (control) or ATO (3.75 or $7.5 \mathrm{mg} / \mathrm{kg}$ ). No significant differences in baseline tumour volume were observed 
A

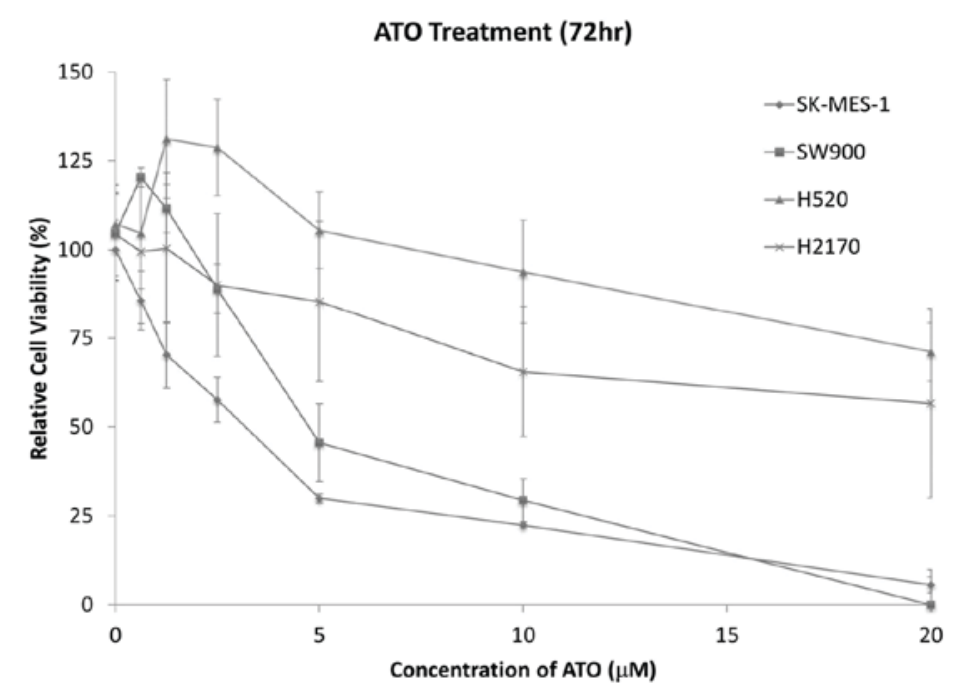

B

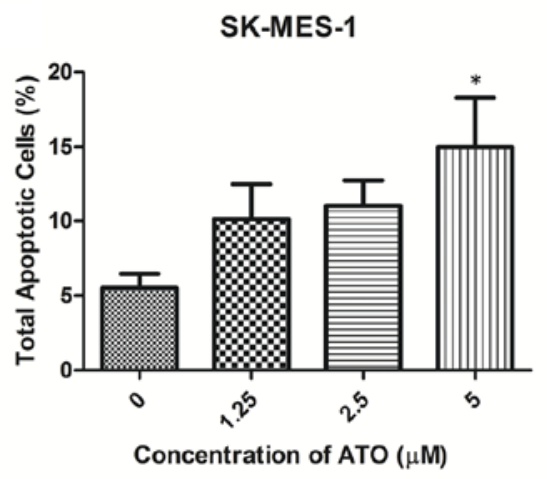

C

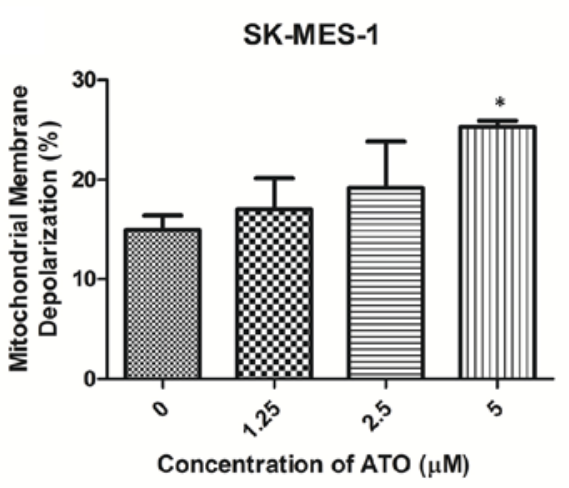

Figure 1. ATO reduced cell viability, induced phosphatidylserine externalization and mitochondrial membrane depolarization in SK-MES-1 cells. (A) SK-MES-1 and SW900 cells were sensitive to ATO treatment with $\mathrm{IC}_{50}$ values of 2.5 and $5 \mu \mathrm{M}$ respectively. $\mathrm{H} 520$ and $\mathrm{H} 2170$ cells were relative resistance to ATO. (B) ATO increased the percentage of cells undergoing apoptosis in SK-MES-1 cells in a dose-dependent manner. (C) ATO increased the proportion of cells undergoing mitochondrial membrane depolarization in SK-MES-1 cells in a dose-dependent manner. Results were measured in triplicate experiments. ${ }^{*} \mathrm{P}<0.05$, compared with the control group. $\mathrm{ATO}$, arsenic trioxide; $\mathrm{IC}_{50}$, half-maximal inhibitory concentration.

between each group (Fig. 3A). The tumour size in control group of the SW900 xenograft model reached the humane endpoint on day 9, when mice were sacrificed and tumours were collected. Only high-dose ATO $(7.5 \mathrm{mg} / \mathrm{kg})$ significantly suppressed tumour growth compared with the control group $(\mathrm{P}=0.0425$; Fig. 3A). There were no evident toxic effects due to ATO treatment. Western blot analysis demonstrated significant downregulation of Bcl-2 and E2F1 expression in tumour samples following $7.5 \mathrm{mg} / \mathrm{kg}$ ATO treatment $(\mathrm{P}<0.05$; Fig. 3B). Hematoxylin and eosin staining revealed more apoptotic bodies in the $7.5 \mathrm{mg} / \mathrm{kg}$ ATO group compared with the $3.75 \mathrm{mg} / \mathrm{kg}$ and control groups (Fig. 3D).

\section{Discussion}

Data from the present study demonstrated that ATO significantly decreases the viability of the SK-MES-1 and SW900 SCC cell lines within clinically achievable concentrations (13). ATO induced $\mathrm{G}_{2} / \mathrm{M}$ phase cell cycle arrest and activated apoptosis by upregulating a number of pro-apoptotic proteins. In addition, proteins associated with DNA replication and repair, including E2F1 and TYMS were downregulated following ATO treatment. Furthermore, ATO treatment significantly reduced tumour growth in vivo in a SW900 xenograft model.

ATO is a traditional Chinese medicine that has been used clinically as an anti-cancer agent in APL, with or without combined use of all-trans retinoic acid (14). ATO inhibits cell growth in solid tumours other than non-haematological carcinoma, including colorectal carcinoma (15). ATO induces apoptosis in lung adenocarcinoma (11) and SCLC in vitro and in vivo (9). However, the effect of ATO in SCC remains unknown.

Phosphatidylserine externalization is a recognition ligand for phagocytes to detect apoptotic cells (16). Phosphatidylserine externalization has been observed in H841 SCLC cells (9) and H23 lung adenocarcinoma cells (10). Mitochondrial membrane depolarization is another indicator of apoptosis; it has been demonstrated that ATO can induce mitochondrial membrane depolarization in lung cancer cells (11). DNA damage is typically sensed at the $G_{1} / S$ checkpoint or $G_{2} / M$ checkpoint, leading to either DNA repair or cell apoptosis. ATO treatment has been demonstrated to induce $\mathrm{G}_{2}$ arrest in Calu- 6 cells (1-3 $\mu \mathrm{M})(17)$. 

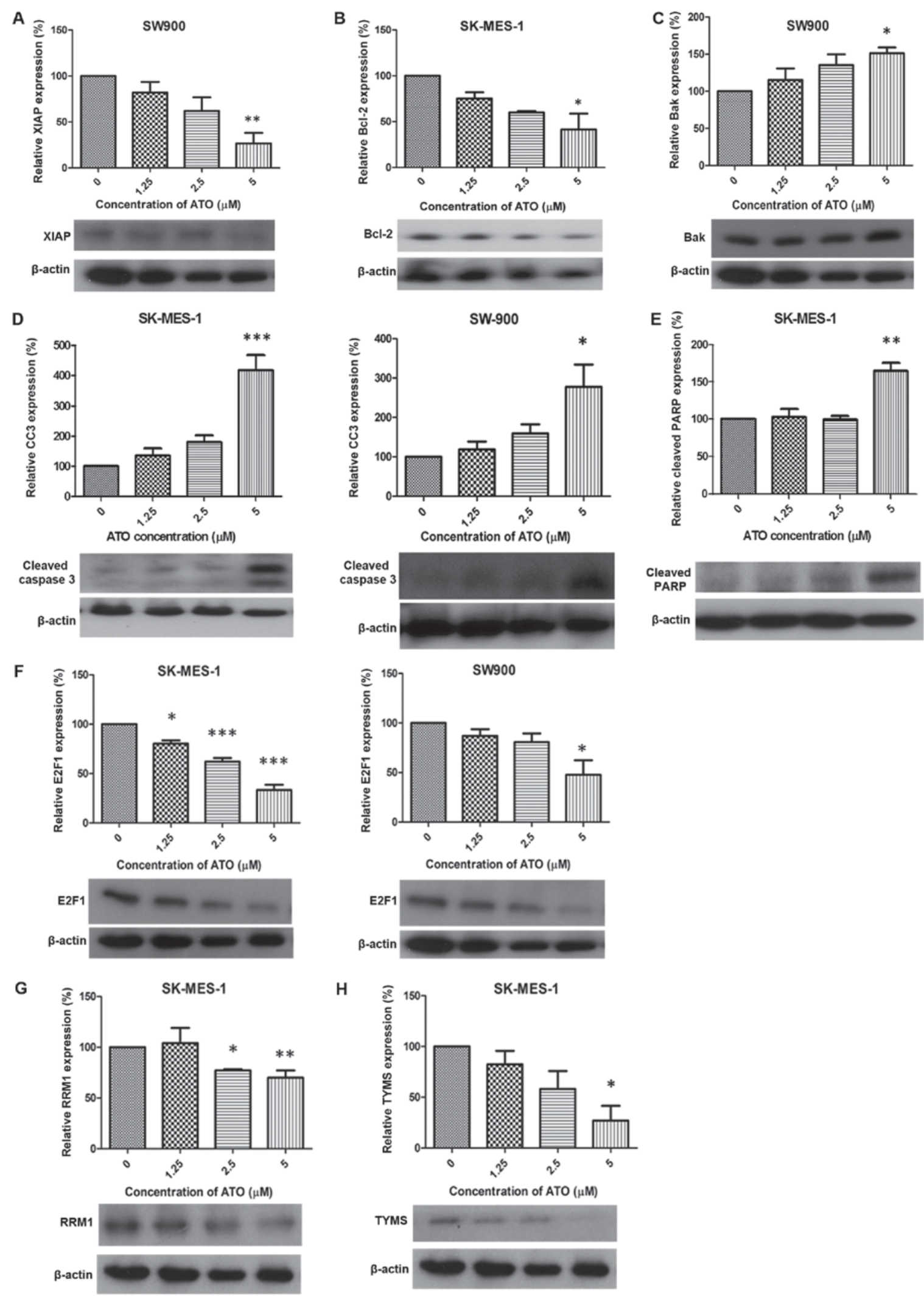

H
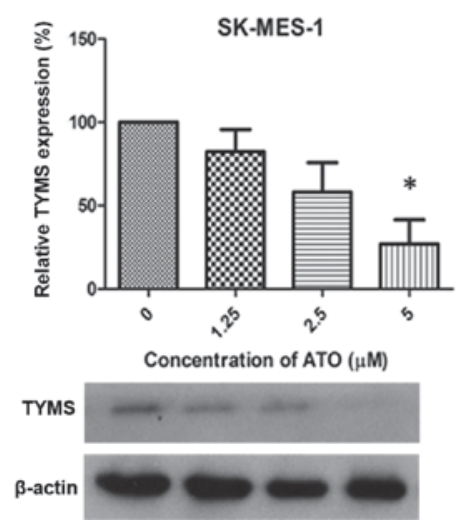

Figure 2. Alteration of protein expression following ATO treatment. ATO induced (A) XIAP downregulation (SW900), (B) Bcl-2 suppression (SK-MES-1), (C) Bak upregulation (SW900), (D) CC3 elevation (SK-MES-1 and SW900), (E) cleaved PARP upregulation (SK-MES-1), (F) E2F1 suppression (SK-MES-1 and SW900), (G) RRM1 downregulation (SK-MES-1) and (H) TYMS suppression (SK-MES-1). Results were measured in triplicate experiments. "P<0.05, ${ }^{* *} \mathrm{P}<0.01$ and ${ }^{* * *} \mathrm{P}<0.001$ compared with the control group. XIAP, X-linked inhibitor of apoptosis; Bcl-2, apoptosis regulator Bcl-2; Bak, Bcl-2 antagonist/killer protein; CC3, cleaved caspase 3; PARP, poly ADP-ribose polymerase; RRM1, ribonucleotide reductase M1; TYMS, thymidylate synthase.

XIAP belongs to the inhibitor of apoptosis protein family, and inhibits apoptosis through activation of the caspase activation pathway via caspase 3,7 and 9 (18). A previous report demonstrated that expression of XIAP was decreased following 
A
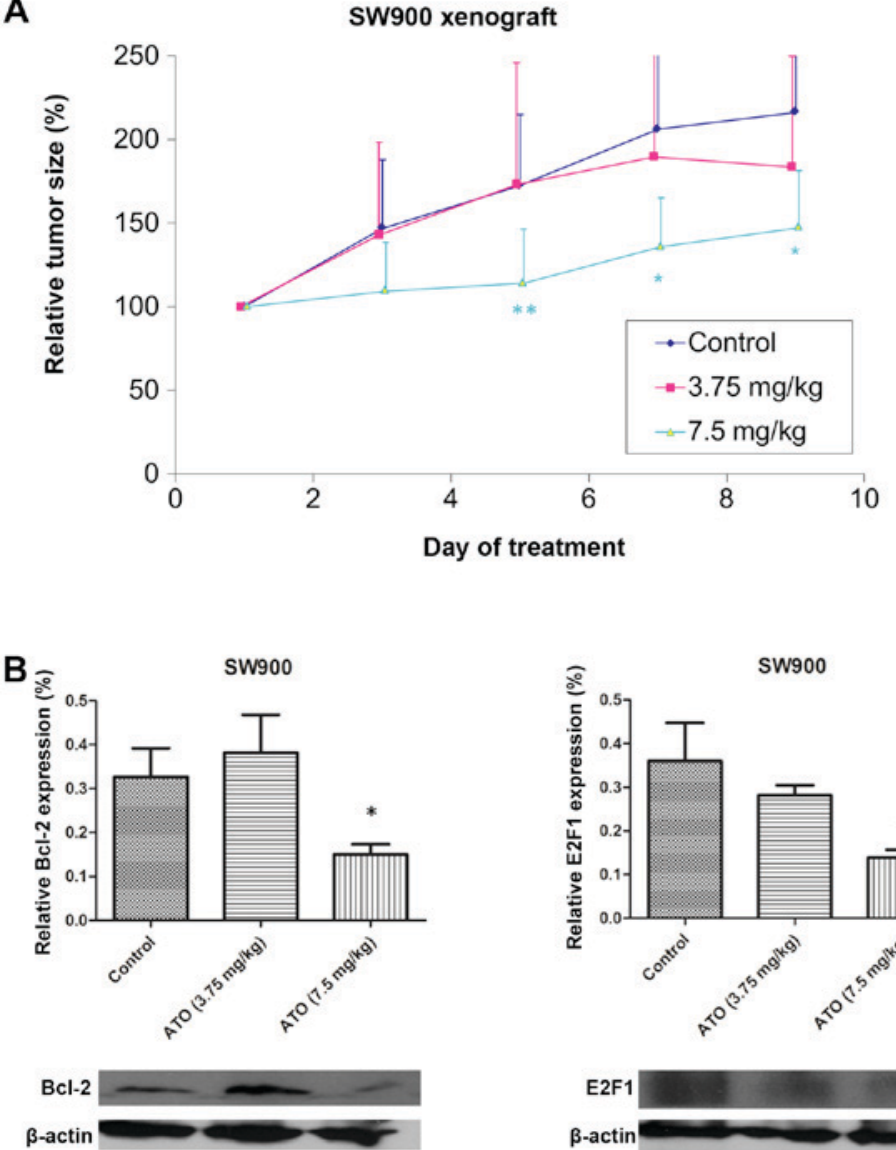

sw900

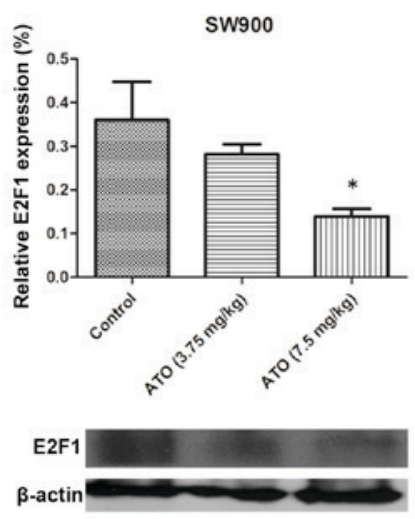

C

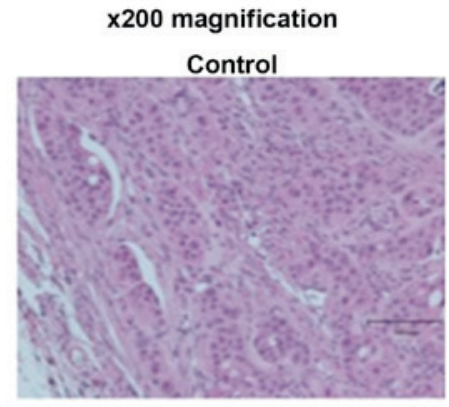

$3.75 \mathrm{mg} / \mathrm{kg}$

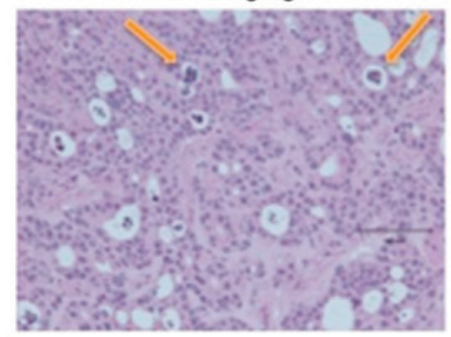

$7.5 \mathrm{mg} / \mathrm{kg}$

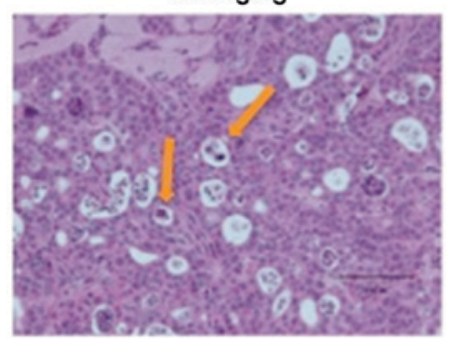

Figure 3. ATO suppressed squamous cell lung carcinoma tumour growth in vivo. (A) ATO (7.5 mg/kg) suppressed tumour growth in SW900 xenograft compared with the control group. (B) The expression of Bcl-2 and E2F1 was downregulated in the $7.5 \mathrm{mg} / \mathrm{kg}$ ATO treatment group compared with the control group. (C) Detection of apoptotic bodies (indicated by arrows) in ATO treatment groups using hematoxylin and eosin staining. ${ }^{*} \mathrm{P}<0.05$, ${ }^{* * *} \mathrm{P}<0.01$ compared with the control.

ATO treatment in SCLC H841 cells (9). Bcl-2 is responsible for the release of apoptotic inducing factor and cytochrome $c$ from the mitochondria, which leads to apoptosis (19). Bcl-2 has been revealed to be downregulated following ATO treatment in lung adenocarcinoma (11) and SCLC (9). Bak is a pro-apoptotic member of the Bcl-2 family of proteins (20) and has been demonstrated to be upregulated in ATO-treated lung adenocarcinoma cell lines, an effect mediated by truncation of BH3-interacting domain death agonist (11).

PARP is a nuclear protein that facilitates DNA repair when cells are undergoing genomic DNA damage from environmental stress (21). PARP is one of the major substrates for executor caspase 3, which represents a hallmark of apoptosis (22). Activation of caspase 3 was observed in lung adenocarcinoma (23) and SCLC (9). Caspase-dependent apoptosis can be divided into the intrinsic (mitochondria-mediated) and extrinsic (death receptor-mediated) pathways (24). Data from the present study demonstrated that in ATO-treated SK-MES-1 cells, downregulation of Bcl-2 was accompanied by mitochondrial membrane depolarization. Cleavage of caspase- 3 and an increase in PARP expression indicated that the intrinsic pathway was activated by ATO in SK-MES-1 cells. By contrast, in ATO-treated SW900 cells, upregulation of Bak did not induce mitochondrial membrane depolarization. Suppression of XIAP and activation of caspase-3 suggested that the extrinsic pathway could be the predominant pathway in this cell type. Therefore, ATO could induce apoptosis via different pathways that were cell-line dependent.

E2F1 is a transcription factor belonging to the E2F family of proteins, which is involved in the $\mathrm{G}_{1}$ to $S$ phase transition and cancer cell proliferation (25). High E2F1 gene expression in NSCLC has been associated with more aggressive phenotype of tumour cells (25). In addition, ATO has previously been demonstrated to downregulate E2F1 and its associated genes, including cyclin A2, c-myc and S-phase kinase associated protein 2 in lung adenocarcinoma (11).

TYMS is a key enzyme for the biosynthesis of thymidylate and is involved in DNA synthesis (26). High tumoral TYMS expression has been associated with poor clinical outcomes (25). In addition, ATO has been demonstrated to downregulate TYMS protein and mRNA expression, leading to tumour growth inhibition in lung adenocarcinoma cell lines (11).

RRM1 encodes the regulatory subunit of ribonucleotide reductase and acts on ribonucleoside diphosphates that are required for deoxynucleotide production (27). A previous clinical study demonstrated that patients with higher tumoral RRM1 expression exhibited a lower survival rate when treated with gemcitabine-based therapy (28). ATO downregulated 
RRM1 expression in lung adenocarcinoma, which may cause inhibition of DNA synthesis (11).

In conclusion, the results from the present study indicate that ATO decreases the viability of SCC SK-MES-1 and SW900 cells within clinically achievable concentrations, partially through apoptosis and inhibition of cell proliferation. Furthermore, ATO induced apoptosis via the intrinsic pathway in SK-MES-1 cells and the extrinsic pathway in SW900 cells. The antitumor effects of ATO were confirmed using a xenograft model.

\section{References}

1. Hu J, Qian GS and Bai CX: Lung Cancer Study Group of Chinese Thoracic S and Chinese Alliance Against Lung Cancer Expert Group: Chinese consensus on early diagnosis of primary lung cancer (2014 version). Cancer 121 (Suppl 17): S3157-S3164, 2015.

2. Ho JC, Tam TC and Lam SK: Salvage therapy beyond targeted therapy in lung adenocarcinoma. Semin Respir Crit Care Med 34 837-844, 2013

3. West H, Harpole D and Travis W: Histologic considerations for individualized systemic therapy approaches for the management of non-small cell lung cancer. Chest 136: 1112-1118, 2009.

4. Ang YL, Tan HL and Soo RA: Best practice in the treatment of advanced squamous cell lung cancer. Ther Adv Respir Dis 9: 224-235, 2015

5. Ravandi F, Estey E, Jones D, Faderl S, O'Brien S, Fiorentino J, Pierce S, Blamble D, Estrov Z, Wierda W, et al: Effective treatment of acute promyelocytic leukemia with all-trans-retinoic acid, arsenic trioxide, and gemtuzumab ozogamicin. J Clin Oncol 27: 504-510, 2009.

6. Rojewski MT, Körper S and Schrezenmeier H: Arsenic trioxide therapy in acute promyelocytic leukemia and beyond: From bench to bedside. Leuk Lymphoma 45: 2387-2401, 2004.

7. Park JW, Choi YJ, Jang MA, Baek SH, Lim JH, Passaniti T and Kwon TK: Arsenic trioxide induces G2/M growth arrest and apoptosis after caspase- 3 activation and bcl-2 phosphorylation in promonocytic U937 cells. Biochem Biophys Res Commun 286 726-734, 2001.

8. Evens AM, Tallman MS and Gartenhaus RB: The potential of arsenic trioxide in the treatment of malignant disease: Past, present, and future. Leuk Res 28: 891-900, 2004.

9. Zheng CY, Lam SK, Li YY and Ho JC: Arsenic trioxide-induced cytotoxicity in small cell lung cancer via altered redox homeostasis and mitochondrial integrity. Int J Oncol 46: 1067-1078, 2015

10. Lam SK, Mak JC, Zheng CY, Li YY, Kwong YL and Ho JC: Downregulation of thymidylate synthase with arsenic trioxide in lung adenocarcinoma. Int J Oncol 44: 2093-2102, 2014.

11. Lam SK, Li YY, Zheng CY, Leung LL and Ho JC: E2F1 downregulation by arsenic trioxide in lung adenocarcinoma. Int $\mathrm{J}$ Oncol 45: 2033-2043, 2014

12. Euhus DM, Hudd C, LaRegina MC and Johnson FE: Tumor measurement in the nude mouse. J Surg Oncol 31: 229-234, 1986.

13. Ardalan B, Subbarayan PR, Ramos Y, Gonzalez M, Fernandez A, Mezentsev D, Reis I, Duncan R, Podolsky L, Lee K, et al: A phase I study of 5-fluorouracil/leucovorin and arsenic trioxide for patients with refractory/relapsed colorectal carcinoma. Clin Cancer Res 16: 3019-3027, 2010.
14. Au WY, Kumana CR, Lee HK, Lin SY, Liu H, Yeung DY, Lau JS and Kwong YL: Oral arsenic trioxide-based maintenance regimens for first complete remission of acute promyelocytic leukemia: A 10-year follow-up study. Blood 118: 6535-6543, 2011.

15. Nakagawa Y, Akao Y, Morikawa H, Hirata I, Katsu K, Naoe T, Ohishi $\mathrm{N}$ and Yagi K: Arsenic trioxide-induced apoptosis through oxidative stress in cells of colon cancer cell lines. Life Sci 70: 2253-2269, 2002.

16. Elmore S: Apoptosis: A review of programmed cell death. Toxicol Pathol 35: 495-516, 2007.

17. Han YH, Kim SZ, Kim SH and Park WH: Arsenic trioxide inhibits the growth of Calu- 6 cells via inducing a $\mathrm{G} 2$ arrest of the cell cycle and apoptosis accompanied with the depletion of GSH. Cancer Lett 270: 40-55, 2008.

18. Silke J, Kratina T, Ekert PG, Pakusch M and Vaux DL: Unlike Diablo/smac, Grim promotes global ubiquitination and specific degradation of $\mathrm{X}$ chromosome-linked inhibitor of apoptosis (XIAP) and neither cause apoptosis. J Biol Chem 279: 4313-4321, 2004.

19. Seite P, Hillion J, d'Agay MF, Gaulard P, Cazals D, Badoux F, Berger R and Larsen CJ: BCL2 gene activation and protein expression in follicular lymphoma: A report on 64 cases. Leukemia 7: 410-417, 1993.

20. Chao DT and Korsmeyer SJ: BCL-2 family: Regulators of cell death. Annu Rev Immunol 16: 395-419, 1998.

21. Satoh MS and Lindahl T: Role of poly (ADP-ribose) formation in DNA repair. Nature 356: 356-358, 1992.

22. Han YH, Kim SZ, Kim SH and Park WH: Arsenic trioxide inhibits growth of As4.1 juxtaglomerular cells via cell cycle arrest and caspase-independent apoptosis. Am J Physiol Renal Physiol 293: F511-F520, 2007.

23. Kim HR, Kim EJ, Yang SH, Jeong ET, Park C, Kim SJ, Youn MJ, So HS and Park R: Combination treatment with arsenic trioxide and sulindac augments their apoptotic potential in lung cancer cells through activation of caspase cascade and mitochondrial dysfunction. Int J Oncol 28: 1401-1408, 2006.

24. Ghobrial IM, Witzig TE and Adjei AA: Targeting apoptosis pathways in cancer therapy. CA Cancer J Clin 55: 178-194, 2005.

25. Huang CL, Liu D, Nakano J, Yokomise H, Ueno M, Kadota K and Wada H: E2F1 overexpression correlates with thymidylate synthase and survivin gene expressions and tumor proliferation in non small-cell lung cancer. Clin Cancer Res 13: 6938-6946, 2007.

26. Rustum YM, Harstrick A, Cao S, Vanhoefer U, Yin MB, Wilke H and Seeber S: Thymidylate synthase inhibitors in cancer therapy: Direct and indirect inhibitors. J Clin Oncol 15: 389-400, 1997.

27. Boukovinas I, Papadaki C, Mendez P, Taron M, Mavroudis D, Koutsopoulos A, Sanchez-Ronco M, Sanchez JJ, Trypaki M, Staphopoulos E, et al: Tumor BRCA1, RRM1 and RRM2 mRNA expression levels and clinical response to first-line gemcitabine plus docetaxel in non-small-cell lung cancer patients. PLoS One 3: e3695, 2008.

28. Rosell R, Danenberg KD, Alberola V, Bepler G, Sanchez JJ, Camps C, Provencio M, Isla D, Taron M, Diz P, et al: Ribonucleotide reductase messenger RNA expression and survival in gemcitabine/cisplatin-treated advanced non-small cell lung cancer patients. Clin Cancer Res 10: 1318-1325, 2004. 